\title{
Belediye Gelirleri Kanununda Düzenlenmiş Olan Yerel Yönetim Gelirlerinin Özellikleri ve Öneriler
}

\author{
Characteristics and Recommendations of Local Administrative \\ Income Regulated in Municipal Income Law
}

Fazıl Aydın ${ }^{*}$

REVIEW

\begin{tabular}{|c|c|}
\hline ARTICLE INFO & A B S T R ACT \\
\hline Submitted : 09.11.2020 & \multirow{9}{*}{$\begin{array}{l}\text { Local governments have different importance for each country. The } \\
\text { priority and importance of local governments throughout the world have } \\
\text { shown increasing momentum. It is only possible for local governments to } \\
\text { fulfill their services by having sufficient resources. In this respect, local } \\
\text { government taxes, fees, fees, and participation shares, which constitute } \\
\text { the most important income sources of local governments, must be } \\
\text { updated and renewed both in terms of legislation and implementation. } \\
\text { These local government revenues have theoretically unique features in } \\
\text { terms of fiscal science. The study, by examining the theoretical features of } \\
\text { local government revenues and suggesting legislative and implementation } \\
\text { suggestions; It is aimed to contribute to the update of local government } \\
\text { taxes, fees, fees, and participation shares. }\end{array}$} \\
\hline Revised : 18.03.2021 & \\
\hline Accepted : 25.03.2021 & \\
\hline Available : 30.06 .2021 & \\
\hline $\begin{array}{l}\text { iThenticate similarity } \\
\text { score: } 18 \%\end{array}$ & \\
\hline JEL classification: & \\
\hline $\mathrm{H} 70, \mathrm{H} 71$ & \\
\hline Keywords: & \\
\hline $\begin{array}{l}\text { Local Governments, } \\
\text { Municipal Revenues, } \\
\text { Tax }\end{array}$ & \\
\hline
\end{tabular}

Cite this article as: Aydın, F. (2021). "Belediye Gelirleri Kanununda Düzenlenmiş Olan Yerel Yönetim Gelirlerinin Özellikleri ve Öneriler", International Journal of Public Finance, 6(1), 159-175.

\begin{tabular}{l} 
MAKALE Bígisi \\
\hline Gönderme: 09.11 .2020 \\
Düzeltme : 18.03 .2021 \\
Kabul : 25.03 .2021 \\
Yayın : 30.06 .2021 \\
\hline iThenticate benzerlik \\
oranı: \%18 \\
\hline
\end{tabular}

ö z
Yerel yönetimler her ülke için ayrı bir öneme sahiptir. Tüm dünyada geçen
süre içinde yerel yönetimlerin önceliği ve önemi giderek artan bir ivme
göstermektedir. Yerel yönetimlerin hizmetlerine yerine getirebilmesi
ancak yeterli kaynaklara sahip olması ile mümkün olabilmektedir. Bu
açıdan yerel yönetimlerin en önemli gelir kaynaklarını oluşturan yerel
yönetim vergi, harç, ücret ve katılım payları gerek mevzuat düzenlemesi

Assist. Prof. PhD., Lecturer, Social Sciences University Of Ankara, Turkey, ORCID No: 0000-0001-72158809, fazil.aydin@hotmail.com 
Aydın, F. (2021). “Belediye Gelirleri Kanununda Düzenlenmiş Olan Yerel Yönetim Gelirlerinin Özellikleri ve Öneriler", International Journal of Public Finance, 6(1), 159-175.

JEL Kodu:

$\mathrm{H} 70, \mathrm{H} 71$

Anahtar Kelimeler:

Yerel Yönetimler,

Belediye Gelirleri,

Vergi ve gerekse uygulama açısından güncel ve yenilenmiş olmalıdır. Söz konusu yerel yönetim gelirleri, maliye bilimi açısından teorik olarak kendisine özgü özellikler taşımaktadır. Çalışmada yerel yönetim gelirlerinin teorik açıdan özellikleri incelenerek ve mevzuat ve uygulama açıdan öneriler belirtilerek; yerel yönetim vergi, harç, ücret ve katılım paylarının güncellenmesine katkı vermek amaçlanmıştır.

\section{Giriş}

Türkiye'de yerel yönetimler anayasal kurumlardır. 1982 Anayasasının 127'nci maddesi "Mahalli İdareler" başlığını taşımaktadır. Türk idare yapısı içinde yerel yönetimlerin yerini ve yerel yönetim sisteminin temel özelliklerini düzenleyen 1982 Anayasasına göre yerel yönetimler "il, belediye veya köy halkının mahallî müşterek intiyaçlarını karşılamak üzere kuruluş esasları kanunla belirtilen ve karar organları, gene kanunda gösterilen, seçmenler tarafından seçilerek oluşturulan kamu tüzelkişileridir". Anayasaya göre yerel yönetimlerin kuruluş ve görevleri ile yetkilerinin yerinden yönetim ilkesine uygun olarak ve yalnızca kanunla düzenlenebilecektir. 1982 anayasası yerel yönetimler üzerinde merkezi idarenin sahip olduğu idari vesayet yetkisinin kapsamını ve gerekçelerini de ayrıntılı bir şekilde düzenleyerek daha önceki anayasalardan farklı bir yol izlemiştir. (T.C. Kalkınma Bakanlığı' 2018: 7). Ayrıca Anayasanın 127'nci maddesi ile yerel yönetimlerin seçilmiş organlarının organlık sıfatını kazanmalarına ilişkin itirazların çözümü ve kaybetmeleri konusundaki denetimin yargı yolu ile olacağı hüküm altına alınmıştır (Türkiye Cumhuriyeti Anayasası, Madde 127).

Büyükşehir belediyelerinin yetki ve görevlerini, çalışma usullerini düzenleyen ve 1984 yılından itibaren yürürlüğe giren 3030 sayılı Büyük Şehir Belediyelerinin Yönetimi Hakkında Kanun Hükmünde Kararnamenin Değiştirilerek Kabulü Hakkında Kanun (09.07.1984 tarih ve 18453 sayılı Resmi Gazete) 5216 sayılı Büyükşehir Belediyelerinin Yönetimi Hakkında Kanun Hükmünde Kararnamenin Değiştirilerek Kabulü Hakkında Kanunda Değişiklik Yapılmasına İlişkin Kanun ile 2004 yılından itibaren yürürlükten kaldırılmıştır (23.07.2004 tarih ve 25531 sayılı Resmi Gazete). Söz konusu 5216 sayılı Kanunda ise 6360 sayılı On Dört İlde Büyükşehir Belediyesi ve Yirmi Yedi İlçe Kurulması ile Bazı Kanun ve Kanun Hükmünde Kararnamelerde Değişiklik Yapılmasına Dair Kanun ile (06.12.2012 tarih ve 28489 sayılı Resmi Gazete) kapsamlı değişiklikler yapılmıştır.

Belediyelerin gelirlerine ilişkin olarak ilk temel düzenleme 1914 yılında Rüsumu Belediye Kanunu ile yapılmış, daha sonra 1924 yılında çıkarılan 423 sayılı Belediye Vergi ve Resimleri Kanunu ile mali durum yeniden düzenlenmiştir. 1948 yılında 5237 sayılı Belediye Gelirleri Kanunu ile yapılan düzenleme, söz konusu düzenleme 1981 yılında yürürlükten kaldırılmış ve 26.5.1981 tarih ve 2464 sayılı Belediye Gelirleri Kanunu yürürlüğe girmiştir. Anayasanın 127'nci maddesinde "Mahalli idarelere görevleriyle orantılı gelir sağlanır." hükmü yer almaktadır. Belediye gelirlerinin en önemli kaynağını 2464 sayılı Belediye Gelirleri Kanunu ve 1319 sayılı Emlak Vergisi Kanunu çerçevesinde 
tahsil edilen gelirler oluşturmaktadır. Söz konusu kanunlar dolayısı ile elde edilen gelirler belediyelerin öz gelirlerini teşkil etmektedir. Ayrıca 5393 sayılı Belediye Kanununun "Belediyenin Gelirleri” başlıklı 59'uncu maddesi çerçevesinde elde edilen gelirler de belediyelerin öz gelirleri kapsamındadır.

Belediye Gelirleri Kanunu ile ilgili düzenleme ve uygulamalar Hazine ve Maliye Bakanlığı ile birlikte İçişleri Bakanlığı ve Çevre ve Şehircilik Bakanlığı tarafından yerine getirilmektedir.

\section{Belediye Gelirleri Kanununda Düzenlenmiş Olan Yerel Yönetim Gelirleri}

Türkiye'de 2464 sayılı Belediye Gelirleri Kanunu kapsamındaki yerel yönetimlere ilişkin gelirler; vergi, harç ve katılma payları olmak üzere temel başlıkta belirlenmiştir. Bu çerçevede 2464 sayılı Belediye Gelirleri Kanununda yer alan yerel yönetim gelirlerinin sınıflandırılmasına aşağıda yer verilmiştir.

\subsection{Yerel Yönetim Vergileri}

2464 sayılı Belediye Gelirleri Kanununda yer alan vergiler; ilan ve reklam vergisi, eğlence vergisi, haberleşme vergisi, elektrik ve havagazı tüketim vergisi, yangın sigortası vergisi ve çevre temizlik vergisi olmak üzere altı ayrı vergi türünden oluşmaktadır. Yerel yönetim vergi türleri içinde yer alan emlak vergisi ise 2464 sayılı Belediye Gelirleri Kanununda yer almayıp 1319 sayılı Emlak Vergisi Kanununda ayrıca düzenlenmiştir.

\subsection{Yerel Yönetim Harçları}

2464 sayılı Belediye Gelirleri Kanununda yer alan harçlar; işgal harcı, tatil günlerinde çalışma ruhsatı harcı, kaynak suları harcı, tellallık harcı, hayvan kesimi muayene ve denetleme harcı, ölçü ve tartı aletleri muayene harcı, bina inşaat harcı, yapı kullanma izni harcı, kayıt ve suret harcı, imar ile ilgili harçlar, işyeri açma izni harcı, muayene, ruhsat ve rapor harcı ve sağlık belgesi harcı olmak üzere onüç ayrı harç türünden oluşmaktadır.

\subsection{Yerel Yönetim Harcamalara Katılma Payları}

2464 sayılı Belediye Gelirleri Kanununda yer alan harcamalara katılma payları; yol harcamalarına katılma payı, kanalizasyon harcamalarına katılma payı ve su tesisleri harcamalarına katılma payı olmak üzere üç ayrı harcamalara katılma payı türünden oluşmaktadır. 


\section{Belediye Gelirleri Kanununda Düzenlenmiş Olan Yerel Yönetim Gelirlerinin Uygulama, Hukuki Yapısı ve Sosyo-Ekonomik Etkileri Açılarından Özellikleri}

Belediye Gelirleri Kanununda düzenlenmiş olan yerel yönetim gelirlerinin uygulama, hukuki yapısı ve sosyo-ekonomik etkileri açılarından özellikleri ayrıntılı olarak aşağıda yer almaktadır.

\subsection{Belediye Gelirleri Kanununda Düzenlenmiş Olan Yerel Yönetim Gelirlerinin Uygulama Açısından Özellikleri}

Belediye Gelirleri Kanununda düzenlenmiş olan yerel yönetim gelirlerinin uygulama açısından özelliklerine aşağıda yer verilmiştir.

- Belediye Gelirleri kapsamındaki yerel yönetim vergileri nispi ve maktu olmak üzere iki şekilde belirlenmektedir.

Nispi vergiler, enflasyon dönemlerinde reel olarak kendilerini korumaktadır. Maktu vergiler ise enflasyon karşısında aşınmaktadır. Ülkemizde Belediye Gelirleri kapsamındaki haberleşme vergisi, elektrik ve havagazı tüketim vergisi, yangın sigortası, eğlence vergisi (biletle girilmeyen yerlerde maktu) gibi vergiler nispi olarak hesaplanırken, ilan ve reklam vergisi, çevre temizlik vergisi ve harçların tamamına yakını (Tellallık harcı ve altyapı kazı izin harcı hariç) maktu olarak hesaplanmaktadır (Yerel Yönetimler Genel Müdürlüğü, 2019: 107).

- Türkiye'de yerel yönetimlerin gelir sistemi, genel bütçe vergi gelirlerinden alınan paylara ve kendilerinin elde ettikleri öz gelirlere dayanmaktadır.

Merkezi idarenin yerel yönetimlere yardım yapmasında esas aldığı ölçütlere bakıldığında; yerel yönetimlerin bulunduğu alanın coğrafi özellikleri, iklim koşulları, nüfus yoğunluğu, hizmet götürdüğü alanın genişliği ve gelişmişlik farklılıkları gibi birçok etken dikkate alınmaktadır (T.C. Kalkınma Bakanlığı, 2017: 94).

- Yerel yönetim katılma payları, harçlar ve resimler, kamu hizmetinden yararlanma ile orantılı olarak ödenmesi ilkesine bağlıdır.

Türkiye'de belediyelerin harç gelirleri vatandaşların belediyeden belirli konularda izin ya da ruhsat alması aşamasında peşin olarak ödedikleri bedellerdir (Arıkboğa, 2016: 282).

- Yerel yönetimlerin ücret gelirleri, miktar ve koşullarını kendilerinin belirleyebildikleri bir öz gelir türüdür.

Ücret gelirleri 2464 sayılı Belediye Gelirleri Kanunu'nun 97'nci maddesinde düzenlenmiştir. Buna göre belediyeler, kanunda harç ya da harcamalara katılma payı 
konusu yapılmayan ve ilgililerin isteğine bağlı olarak yerine getirecekleri her türlü hizmetler için belediye meclisi kararı ile ücret almaya yetkilidir. Vergiler, harçlar ve harcamalara katılma paylarından farklı olarak ücret gelirleri belediyelerin miktar ve koşullarını kendilerinin belirleyebildikleri bir öz gelir türüdür (Arıkboğa, 2016: 282).

\section{- Yerel yönetim vergileri genel kural olarak beyana dayanmaktadır.}

2464 sayılı Belediye Gelirleri Kanununda düzenlenmiş olan ilan ve reklam vergisi, eğlence vergisi, elektrik ve havagazı tüketim vergisi ile haberleşme vergisi beyanname üzerinden tarh ve tahakkuk ettirilerek, beyanname verme süresi içinde ilgili belediyelere ödenir. Su tüketim miktarı esas alınmak sureti ile hesaplanan çevre temizlik vergisi ise su faturasında ayrıca gösterilerek tahakkuk ettirilerek su tüketim bedeli ile birlikte belediyelerce tahsil edilir. Emlak Vergisi Kanununda düzenlenmiş olan ve makale konusu dışında bulunan emlak vergisinde ise Emlak Vergisi Uygulamasında Değişiklikler Yapan 4751 Sayılı Kanun ile 09.04.2002 tarihinden itibaren "Beyan Usulü" kaldırımış ve yalnızca vergi değerini değiştiren nedenlerin bulunması durumunda bildirim vermek yükümlülüğü getirilmiştir. Dolayısı ile 2464 sayılı Belediye Gelirleri Kanununda düzenlenmiş olan ilan ve reklam vergisi, eğlence vergisi, elektrik ve havagazı tüketim vergisi ile haberleşme vergisi beyan usulüne tabi vergilerdir.

Belediyelerde, Vergi Usul Kanununda belirtilen tarh ve tahakkuk usullerinden "beyana dayanan vergi tarhı" ve "idarece vergi tarhı" yöntemleri kullanılmaktadır. Belediye vergileri genel kural olarak beyana dayanmaktadır. 2464 sayılı Belediye Gelirleri Kanununda yer alan vergiler beyana dayanan vergilerdir ve Kanun'da belirtilen dönemlerde düzenli olarak beyan verilmesi gerekmektedir. Emlak vergisinde ise beyan yalnızca başlangıç aşamasında ve kanunda belirtilen durumlar ortaya çıktığında (binaların yeni inşası ya da vergi değerini tadil eden sebeplerin meydana gelmesi gibi) verilmekte, bunun dışında vergi daha önce bildirilen bilgiler esas alınarak her yıl belediyeler tarafından tahakkuk ettirilmektedir (Arıkboğa, 2015: 11).

- Yerel yönetim gelirlerinin tahsil yetkisi, belediye türlerine göre farklılık

\section{taşımaktadır.}

Büyükşehir belediyeleri, Kanunda sayılan vergilerden yalnızca ilan ve reklam vergisi, eğlence vergisi ve yangın sigorta vergisini tahsil etmekle yükümlüdür. İlçe belediyeleri tarafından tahsil edilen çevre temizlik vergisinden büyükşehir belediyelerine \%20 oranında pay verilmektedir. Yangın sigorta vergisi ise, itfaiye hizmetlerinin büyükşehir belediyeleri tarafından yürütülmesi nedeniyle büyükşehir belediyelerinin bulunduğu illerde büyükşehir belediyeleri tarafından tahsil edilmekte, ilçe belediyeleri bu vergiyi tahsil etmemektedir (Arıkboğa, 2016: 281). 


\subsection{Belediye Gelirleri Kanununda Düzenlenmiş Olan Yerel Yönetim Gelirlerinin Hukuki Yapısı Açısından Özellikleri}

Belediye Gelirleri Kanununda düzenlenmiş olan yerel yönetim gelirlerinin hukuki yapısı açısından özellikleri aşağıda yer almaktadır.

- Usul hükümleri açısından Belediye Gelirleri Kanununa göre alınacak vergi, harç ve katılma payları hakkında Vergi usul kanunu ve Amme Alacaklarının Tahsil Usulü Hakkında Kanun hükümleri uygulanır.

Belediye Gelirleri Kanununda aksine hüküm bulunmayan durumlarda usul hükümleri açısından Belediye Gelirleri Kanununa göre alınacak vergi, harç ve katılma payları hakkında 213 sayılı Vergi Usul Kanunu ile 6183 sayılı Amme Alacaklarının Tahsil Usulü Hakkında Kanun ve bunların ek ve tadillerine dair esaslar uygulanır.

- Belediye Gelirleri Kanununda yer alan maktu vergi ve harçlar tarifelerinin belirlenme şekilleri kanunda yer almaktadır.

Belediye Gelirleri Kanununa göre belediyeler; nüfusları ile ekonomik ve sosyal gelişme durumlarına göre Hazine ve Maliye Bakanlığı ile Cumhurbaşkanlığı Strateji ve Bütçe Başkanlığının görüşü alınarak Çevre ve Şehircilik Bakanlığınca beş gruba ayrıır ve Resmi Gazete'de ilan edilir. Söz konusu belediye grupları her üç yılda bir yenilenir.

Cumhurbaşkanı; konutlara ait çevre temizlik vergisi tutarlarını yöreler, belediyelerin nüfusları ve bina grupları itibarıyla ayrı ayrı dörtte birine kadar indirmeye veya yarısına kadar artırmaya yetkilidir. Cumhurbaşkanı; işyerleri ve diğer şekilde kullanılan binalara ait Çevre Temizlik Vergisi tarifesindeki bina gruplarını belirlemeye ve tutarları yöreler, belediyelerin nüfusları ve bina grupları itibarıyla ayrı ayrı dörtte birine kadar indirmeye veya yarısına kadar artırmaya yetkilidir.

Cumhurbaşkanı; Belediye Gelirleri Kanununda yer alan harcamalara katılma payları ödeme sürelerini, ilgili belediyelerin teklifi üzerine, beş yıla (peşin ödemelerde bir yıla) kadar uzatmaya ve buna göre taksit sürelerini tespit etmeye yetkilidir. Cumhurbaşkanınca bu yetkinin kullanılması halinde, uzatılan ödeme süreleri için belediyeler, belediye meclislerinin kararı üzerine ve 6183 sayılı Amme Alacaklarının Tahsil Usulü Hakkında Kanun hükümleri uyarınca alınan tecil faizi oranını aşmamak üzere faiz alabilirler.

Cumhurbaşkanı; Belediyelerin (5016 sayılı Büyükşehir Belediyelerinin Yönetimi Hakkında Kanun Hükmünde Kararnamenin Değiştirilerek Kabulü Hakkında Kanunda Değişiklik Yapılmasına ïlişkin Kanunun uygulandığı şehirlerde hizmeti veren belediyelerin) görüşü alınmak suretiyle, harcamalara katılma paylarını 1/2'ye (peşin ödemede $1 / 3$ 'e) kadar indirmeye, pay çeşitlerine göre farklılaştırma yapmaya, payların ödenecek miktarını birlikte veya pay çeşitlerine göre ayrı ayrı olmak üzere Çevre ve Şehircilik Bakanlığınca bildirilecek son genel nüfus sayımı sonuçlarını da dikkate almak 
suretiyle ve belediyeler itibariyle tespit etmeye yetkilidir. Cumhurbaşkanı; altyapı kazı izni harcını belediye grupları itibarıyla bu oranı yarısına kadar indirmeye, on katına kadar artırmaya yetkilidir.

Cumhurbaşkanı, Belediye Gelirleri Kanununda en az ve en çok miktarları gösterilen vergi ve harçların tarifelerini belediye grupları itibarıyla tayin ve tespit eder. Ancak, ilan ve reklam vergisi, biletle girilmesi zorunlu olmayan eğlence yerlerinde eğlence vergisi, işgal harcı, tatil günlerinde çalışma ruhsatı harcı ve işyeri açma izni harcı maktu vergi ve harç tarifeleri, Belediye Gelirleri Kanununda belirtilen en alt ve en üst sınırları aşmamak koşulu ile mahallin çeşitli semtleri arasındaki sosyal ve ekonomik farklılıklar göz önünde tutularak ilgili belediye meclislerinin önerisi üzerine Cumhurbaşkanı tarafından tespit edilir.

Cumhurbaşkanı Belediye Gelirleri Kanununda yer alan maktu vergi ve harçların en az ve en çok miktarlarını belirleyen hadleri birlikte veya ayrı ayrı veya her vergi ve harç ile ilgili tarifelerde yer alan en az ve en çok hadleri birlikte veya ayrı ayrı on katına kadar artırmaya ve Belediye Gelirleri Kanununda yer alan hadlerden az ve bu hadlerin on katından çok olmamak üzere yeni hadler tespit etmeye ve eğlence vergisi oranlarını birlikte veya ayrı ayrı bir katına kadar artırmaya veya sıfıra kadar indirmeye yetkilidir.

Cumhurbaşkanı tarafından belli edilen uluslararası kuruluşlar ile bu kuruluşların yabancı devlet uyruğundaki memurları ve anlaşmalar gereğince diplomatik muafiyet tanınan personel Belediye Gelirleri Kanunu hükümlerinden muaftırlar.

\subsection{Belediye Gelirleri Kanununda Düzenlenmiş Olan Yerel Yönetim Gelirlerinin Sosyo-Ekonomik Etkileri Açısından Özellikleri}

Belediye Gelirleri Kanununda düzenlenmiş olan yerel yönetim gelirlerinin sosyoekonomik etkileri açısından özelliklerine aşağıda yer verilmiştir. artırmaktadır.

- Kentleşmenin yaygınlaşmasına uygun olarak yerel yönetim gelirlerinin önemi

Günümüzde dünya bir yandan küreselleşirken diğer yandan yerelleşmektedir. Küreselleşmeyle birlikte dünyada devletlerin yerini kentler ve ör-gütlenmiş kurumlar almaktadır. Bu sürece uygun olarak son yıllarda kentlerin ekonomik ve sosyal yaşamdaki yeri ve önemi gittikçe artmaktadır (Bülbül, 2013: 167).

Günümüz dünyasında ekonomi, sosyal, siyasal ve teknoloji alanında yaşanan hızlı gelişmeler yerel hizmet niteliği taşıyan ihtiyaçları da artırmaktadır. Bu gelişmeler merkezi yönetim yanında yerel yönetimlerin de istikrarlı ve etkin bir mali yapıya kavuşturulmasını, artan hizmet ihtiyacını karşılamak için yeterli kaynağın teminini zorunlu kılmaktadır (Ulusoy, 2000: 140). 


\section{- Yerel yönetim gelirleri, yerel yönetimler için en önemli gelir kaynağıdır.}

Günümüzde şehirleşme hareketlerinin her türlü tahminin ötesinde gelişmesi, şehir niteliğindeki yerleşim alanlarında yaşayan nüfusun hızla artması, şehir halkının giderek sosyal, ekonomik ve kültürel ihtiyaçlarının çoğalması ve nihayet şehirlerin çağın gereklerine göre yeniden tanzim ve imar çabaları, bu konudaki giderlerin geniş ölçüde artması sonucunu doğurmuş ve bu durum eski şartlara ve anlayışlara göre kurulmuş olan yerel yönetim finans sistemlerinin yeni ve doyurucu kaynaklara sahip olacak biçimde geliştirilmesini zorunlu kılmıştır (Yiğit, vd., 2017: 69).

Ülkemizde belediyelerin en önemli sorunlarından biri de gelir yetersizliğidir. Gelir yetersizliklerinin temel nedeni olarak, nüfusun hızla kentlerde yoğunlaşması ve kentsel gelişmeler karşısında, belediyelerin görev ve sorumluluklarına göre bir gelir artışının sağlanamamış olması gösterilebilir (Yüksel, 2003: 53).

Kamu hizmetlerinin yürütülmesinde, merkezi yönetimler ile yerel yönetimler arasında görev ve gelir paylaşımı, "merkeziyetçilik" ve "ademi merkeziyet" ilkeleri ile "mali tevzin" kavramının sıkça gündeme gelmesine neden olmaktadır. Bu paylaşımda, yerel idarelere düşen görev payının artması, bu yönetimlerin gelire olan gereksinimini arttırmaktadır. Yerel yönetimlerin gelirleri doğal olarak tüm kamu yönetimlerinde olduğu gibi esas itibariyle vergiye dayanmaktadır (Öz, 2012: 64). sahiptir.

- Yerel yönetim gelirleri, mali açıdan yerel yönetimlere güç sağlayıcı özelliğe

Yerel yönetimlerin mali açıdan yapılarının güçlü olmasını sağlayıcı en büyük etken, özellikle öz gelirlerinin etkin ve verimli olmasıdır. Yerel yönetimlerin mali yapılarının güçlü olması, merkezi yönetimin yükünü azaltıcı etki yaratarak, merkezi yönetimin de güçlü olmasını sağlamaktadır.

Kamusal hizmet arzı bakımından merkezi yönetimi tamamlayıcı bir işleve sahip olan belediyelerin görev ve sorumlulukları arttıkça, merkezi yönetimin kamusal hizmet sunum konusundaki rolü azalmakta ve merkezi yönetim daha makro plan ve programlara yoğunlaşabilmektedir. Ayrıca belediyeler sayesinde yerel düzeyde piyasa benzeri bir rekabet ortamının oluşması ve kamusal hizmet arzında yenilikçi yöntemlerin denenmesi gibi birçok gelişmenin altyapısı oluşturulmaktadır (Ulusoy, vd., 2019: 169).

\section{- Yerel yönetim harçları, taşınmazın değerini doğrudan etkilemektedir.}

Başka bir ifadeyle, kentlerde yatırımların ve yerel kamu hizmetlerinin seviyesinde ve kalitesindeki artış, pozitif dışsallık oluşturmakta veya kentsel rant yaratmakta veya taşınmaz değerlerinde kapitalize olmakta, nüfus artışı gibi başka faktörlerin de etkisiyle taşınmaz değerleri yükselmektedir (Önder, vd., 2017: 59).

Bina inşaat harcı, inşaat ruhsatının alınması sırasında ödenen bir harçtır ve yapılacak binanın gecekondu olmaması için en önemli önkoşulu sağlayan hukuki bir işlemdir. Bina inşaat harçları, yapılacak binanın yüzölçümüne göre değişmekte ve 
işyerleri için daha yüksek tutarlara ulaşmaktadır. Böyle bir ruhsatın varlığı ya da yokluğu taşın-mazın değerini doğrudan etkilemektedir (Önder, vd., 2017: 114).

Gerek kullanıcı harçları, gerekse katılım payları yoluyla vergilenen ya da özel olarak vergilenmeyen yerel kamu hizmetleri taşınmaz değerlerini etkilemektedir (Önder, vd., 2017: 114).

- Harcamalara katılma payları, sunulan kamu hizmetinin finansmanının yararlananlardan sağlanması esasına göre alınan bir kamu geliri türüdür.

Belediye Gelirleri Kanununa göre harcamalara katılma payları, bir program dahilinde veya istek üzerine doğrudan doğruya yapılan işlerde, bu hizmetler dolayısıyla yapılan giderlerin tamamıdır (Şahin İpek 2018: 469). 2464 Sayılı Belediye Gelirleri Kanunu'nun 86-94 maddeleri arasında harcamalara katılım payı düzenlenmiştir. Buna göre, Belediyeler tarafından yapılmış yol, kanalizasyon ve su tesisleri harcamalarına katılım payı alınmaktadır. Bu harcamalar gayrimenkul değerini artırıcı nitelikte olduğu için, katılma payı mükellefiyetini harcamanın yapıldığı bölgedeki gayrimenkul sahipliği ile ilişkilendirmiştir (Yılmaz, 2008: 78).

Harcamalara katılım payı uzun yıllardır yasal bir düzenleme olarak bulunmasına karşın çeşitli sebepler ile uygulanmamış veya eksik uygulanmış bir yerel kamu geliri olarak kalmıştır. Artan şehir nüfusu karşısında kaynak ihtiyacı belediyeleri bu yerel gelire olan dikkati artırmıştır (Aslan, 2014: 129).

2464 sayılı Kanun'da tanımlanan durumlarda belediyelerin yol, su ve kanalizasyon harcamalarına katılma payı alma yetkisi bulunmaktadır. Harcamalara katılma payları belediyelerin Kanun'da belirtilen yol, su ve kanalizasyon işleri için yapacakları harcamaları finanse etmek amacıyla ilgililerden aldıkları katılım paylarıdır. Payların hesaplanması konusundaki sınırlamalar, ilgililere nasıl paylaştırılacağı ve tahsilata ilişkin bazı usuller 2464 sayılı Kanun ile belirlenmiştir (Arıkboğa, 2016: 282).

Ülkemiz açısından oluşan kentsel rantların vergilendirilmesi aşamasında geçmiş dönem uygulamalarına bakıldığında 1948 tarihli 5237 sayılı Belediye Gelirleri Kanununda yer alan "Değerleme Resmi" en güzel örnektir. Yine 1970 tarihli Finansman Kanunu ile getirilen ve 1970-1982 yılları arasında uygulanan "Gayrimenkul Kıymet Artışı Vergisi" de rantların kamuya aktarılmasında önemli vergi uygulamaları olarak karşımıza çıkmaktadır. Günümüzde ise bazı kaynaklarda Belediye Gelirleri Kanununda yer alan harcamalara katılma paylarının bir rant vergisi olduğu ifade edilmektedir. Ancak harcamalara katılma payları taşınmazlarda oluşan değer artışlarını vergilendirmemekte öngörülen harcamanın bir kısmını finanse etmek için alınmaktadır. Bu şekliyle vergiden uzak bir yapıdadır. 2464 sayılı Belediye Gelirleri Kanununda yer alan harcamalar katılma payları yol harcamalarına katılma payları, kanalizasyon harcamalarına katılma payları ve su tesisi harcamalarına katılma paylarından oluşmaktadır. Mevcut düzenlemede vergi hukuku açısından ilginç bir durumda söz konusudur. Yol harcamalarına katılma paylarını düzenleyen madde hükmünde bu katılma payı ile ilgili olarak "alınabilir" ifadesi kullanılmasına karşın kanalizasyon ve su tesisi harcamalarına 
katılma paylarına ilişkin madde hükmünde ise "alınır" ifadesi yer almaktadır. Dolayısıyla harcamalara katılma paylarından biri olan ve rant vergisi olarak ifade edilebilen yol harcamalarına katılım payının bırakın rant vergisi olmasını bir zorunluluk içermediği için zorunlu yükümlülük olarak değerlendirilip değerlendirilemeyeceği bile tartışılır bir durumdadır (Canatay, 2016: 200).

\section{Belediye Gelirleri Kanunu Kapsamındaki Yerel Yönetim Gelirlerinin Sayısal Görünümü}

2015-2020 yılları arasındaki beş yıllık dönemde Türkiye'de Belediye Gelirleri Kanunu kapsamındaki yerel yönetim vergi ve harç gelirleri aşağıdaki Tablo 1'de yer almaktadır.

Tablo 1: Türkiye'de Belediye Gelirleri Kanunu Kapsamındaki Yerel Yönetim Vergi ve Harç Gelirleri (2015-2020 Dönemi) (Bin TL)

\begin{tabular}{|l|c|c|c|c|c|c|}
\hline \multirow{2}{*}{$\begin{array}{c}\text { Vergi/Harç } \\
\text { (Türü) }\end{array}$} & \multicolumn{7}{c|}{ Ylllar itibarıyla Vergi/Harç (TL) } \\
\cline { 2 - 7 } & $\mathbf{2 0 1 5}$ & $\mathbf{2 0 1 6}$ & $\mathbf{2 0 1 7}$ & $\mathbf{2 0 1 8}$ & $\mathbf{2 0 1 9}$ & $\mathbf{2 0 2 0}$ \\
\hline Çevre Temizlik Vergisi & 395.308 & 474.752 & 465.615 & 541.695 & 622.462 & 514.406 \\
\hline Eğlence Vergisi & 187.999 & 208.684 & 244.064 & 268.766 & 327.662 & 183.467 \\
\hline Yangın Sigorta Vergisi & 31.141 & 31.868 & 35.945 & 39.391 & 44.017 & 34.155 \\
\hline Illan ve Reklam Vergisi & 345.502 & 423.651 & 445.548 & 481.033 & 442.666 & 340.749 \\
\hline Haberleşme Vergisi & 40.852 & 39.522 & 43.164 & 51.843 & 58.466 & 47.286 \\
\hline $\begin{array}{l}\text { Elektrik ve Havagazı } \\
\text { Tüketim Vergisi }\end{array}$ & 1.307 .194 & 1.177 .003 & 1.265 .951 & 1.592 .837 & 2.249 .966 & 1.775 .488 \\
\hline Bina İnşaat Harcı & 775.405 & 915.182 & 1.247 .684 & 723.106 & 409.557 & 391.652 \\
\hline $\begin{array}{l}\text { Hayvan Kesimi } \\
\text { Muayene ve Denetleme } \\
\text { Harcı }\end{array}$ & 19.804 & 17.004 & 14.909 & 15.203 & 18.381 & 17.336 \\
\hline İşgal Harcı & 376.175 & 431.652 & 469.005 & 468.418 & 513.461 & 320.917 \\
\hline İşyeri Açma İzni Harcı & 75.448 & 82.809 & 82.398 & 81.453 & 98.178 & 76.546 \\
\hline Kaynak Suları Harcı & 5.846 & 9.391 & 7.230 & 6.998 & 7.562 & 6.025 \\
\hline $\begin{array}{l}\text { Ölçü ve Tartı Aletleri } \\
\text { Muayene Harcı }\end{array}$ & 1.888 & 2.273 & 1.317 & 1.324 & 1.427 & 1.129 \\
\hline $\begin{array}{l}\text { Tatil Günlerinde } \\
\text { Çalışma Ruhsatı Harcı }\end{array}$ & 24.534 & 8.550 & 7.005 & 4.334 & 5.143 & 4.474 \\
\hline Tellallık Harcı & 84.792 & 96.259 & 113.114 & 110.576 & 137.203 & 78.211 \\
\hline $\begin{array}{l}\text { Yapı Kullanma İzni } \\
\text { Harcı }\end{array}$ & 250.280 & 234.567 & 291.126 & 261.601 & 209.419 & 164.403 \\
\hline \multicolumn{1}{|c|}{ TOPLAM } & $\mathbf{3 . 9 2 2 . 1 6 8}$ & $\mathbf{4 . 1 5 3 . 1 6 7}$ & $\mathbf{4 . 7 3 4 . 0 7 5}$ & $\mathbf{4 . 6 4 8 . 5 7 8}$ & $\mathbf{5 . 1 4 5 . 5 7 0}$ & $\mathbf{3 . 9 5 6 . 2 4 4}$ \\
\hline
\end{tabular}

Kaynak: Muhasebat Genel Müdürlüğü’nün mahalli idareler bütçe istatistiklerinden yararlanılarak yazar tarafından düzenlenmiştir. https://muhasebat.hmb.gov.tr/mahalli-idareler-butce-istatistikleri, (16.03.2021)

$(*)$ Emlak vergisi dahil edilmemiştir. 
Yukarıdaki Tablo 1'de 2015-2020 yılları arasındaki beş yıllık dönemde Türkiye'de Belediye Gelirleri Kanunu kapsamındaki yerel yönetim vergi ve harç gelirlerindeki değişim ve gelişmeler yer almaktadır. Söz konusu tabloda belde, ilçe, büyükşehir ve büyükşehir dışındaki belediyeler itibarıyla ayrım yapılmaksızın tüm belediyelerin 20152020 yılları arasındaki beş yıllık dönem içindeki yerel yönetimlerin tüm vergi ve harç gelirlerinin tutarları dikkate alınmıştır.

Tablo 1'de görüldüğü üzere, 2015-2020 döneminde Türkiye'de Belediye Gelirleri Kanunu kapsamındaki yerel yönetim vergi ve harç gelirlerinin toplam tutarları içinde en yüksek tutara elektrik ve havagazı tüketim vergisi, en düşük tutara ise ölçü ve tartı aletleri muayene harcı sahiptir.

Tablo 1'deki veriler incelendiğinde 2019 yılı ile 2020 yılı karşılaştırmasında Belediye Gelirleri Kanunu kapsamındaki tüm yerel yönetim vergi ve harç gelirlerinde büyük miktarlarda gelir düşüklüğünün olduğu ve söz konusu gelirlerin 2019 yılında toplam tutarının 5.145.570.000 TL iken, 2020 yılında söz konusu toplam tutarın 3.956.244.000 TL olarak gerçekleştiği ve 2019 yılına göre 2020 yılında toplam olarak 1.189.326.000 TL gelir kaybının gerçekleştiği görülmektedir. Dolayısı ile Belediye Gelirleri Kanunu kapsamındaki tüm yerel yönetim vergi ve harç gelirlerinde 2019 yılına göre 2020 yılında \%23,11 oranında gelir kaybı gerçekleşmiştir. 2019 yılına göre 2020 yılında gerçekleşen 1.189.326.000 TL tutarındaki gelir kaybının Covid 19 pandemi salgınından kaynaklandığı değerlendirilebilir.

Buna karşın Tablo 1'deki verilere göre; ilan ve reklam vergisi, bina inşaat harcı, ölçü ve tartı aletleri muayene harcı, tatil günlerinde çalışma ruhsatı harcı ve yapı kullanma izni harcı dışındaki 2015-2020 yılları arasındaki beş yıllık dönemde Türkiye'de Belediye Gelirleri Kanunu kapsamındaki yerel yönetim vergi ve harç gelirlerindeki en büyük gelir artışının ise 580.908.000 TL artış ile 2017 yılında gerçekleştiği görülmektedir.

2018-2020 yılları arasındaki üç yıllık dönemde Türkiye'de belediye türleri itibarı ile Belediye Gelirleri Kanunu kapsamındaki yerel yönetim vergi ve harç gelirleri Tablo 2'de yer almaktadır.

Aşağıdaki Tablo 2'de görüldüğü üzere, 2020 yılında Türkiye'de belediye türleri itibarıyla Belediye Gelirleri Kanunu kapsamındaki yerel yönetim vergi ve harç gelirlerinin toplam tutarı içinde ilçe ve belde belediyeleri payı $\% 81,88$, büyükşehir dışı il belediyeleri payı $\% 8,83$ ve büyükşehir belediyeleri payının ise $\% 9,20$ şeklinde gerçekleşmiştir. Dolayısı ile 2020 yılında Türkiye'de belediye türleri itibarıyla Belediye Gelirleri Kanunu kapsamındaki yerel yönetim vergi ve harç gelirlerinden en yüksek payı ilçe ve belde belediyeleri alırken, en düşük payı ise büyükşehir dışı il belediyeleri almıştır. 
Aydın, F. (2021). “Belediye Gelirleri Kanununda Düzenlenmiş Olan Yerel Yönetim Gelirlerinin Özellikleri ve Öneriler", International Journal of Public Finance, 6(1), 159-175.

Tablo 2: Türkiye'de Belediye Türleri İtibarı ile Belediye Gelirleri Kanunu Kapsamındaki Yerel Yönetim Vergi ve Harç Gelirleri (2018-2020 Dönemi) (Bin TL)

\begin{tabular}{|c|c|c|c|c|c|c|c|c|c|}
\hline \multirow{2}{*}{$\begin{array}{l}\text { Vergi/Harç } \\
\text { (Türü) }\end{array}$} & \multicolumn{3}{|c|}{ İlçe ve Belde Belediyeleri } & \multicolumn{3}{|c|}{ Büyükşehir Dışı İ Belediyeleri } & \multicolumn{3}{|c|}{ Büyükşehir Belediyeleri } \\
\hline & 2018 & 2019 & 2020 & 2018 & 2019 & 2020 & 2018 & 2019 & 2020 \\
\hline $\begin{array}{l}\text { Çevre Temizlik } \\
\text { Vergisi }\end{array}$ & 466.998 & 550.388 & 447.373 & 58.749 & 1.192 .400 & 62.893 & 15.901 & 769 & 4.135 \\
\hline Eğlence Vergisi & 122.296 & 158.858 & 72.355 & 2.124 & 11.478 & 1.222 & 144.346 & 166.275 & 109.890 \\
\hline $\begin{array}{l}\text { Yangin Sigorta } \\
\text { Vergisi }\end{array}$ & 4.110 & 4.305 & 4.325 & 3.752 & 252.183 & 3.018 & 31.529 & 36.023 & 26.812 \\
\hline $\begin{array}{l}\text { İlan ve Reklam } \\
\text { Vergisi }\end{array}$ & 197.507 & 170.624 & 139.422 & 37.296 & 4.856 & 26.755 & 246.228 & 232.906 & 174.571 \\
\hline $\begin{array}{l}\text { Haberleşme } \\
\text { Vergisi }\end{array}$ & 47.873 & 53.719 & 43.126 & 3.769 & 271.525 & 4.029 & 201 & 115 & 131 \\
\hline $\begin{array}{l}\text { Elektrik ve } \\
\text { Havagazı } \\
\text { Tüketim Vergisi }\end{array}$ & 1.459 .047 & 2.061 .472 & 1.622 .695 & 128.645 & 3.253 & 148.691 & 5.046 & 5.296 & 4.036 \\
\hline $\begin{array}{l}\text { Bina Inşaat } \\
\text { Harcı }\end{array}$ & 652.689 & 369.103 & 341.447 & 66.571 & 110.220 & 49.279 & 3.672 & 1.673 & 822 \\
\hline $\begin{array}{l}\text { Hayvan Kesimi } \\
\text { Muayene ve } \\
\text { Denetleme } \\
\text { Harcı }\end{array}$ & 10.390 & 12.325 & 12.727 & 1.149 & 44.333 & 1.120 & 3.664 & 4.663 & 3.489 \\
\hline İşgal Harcı & 397.890 & 442.456 & 273.755 & 41.526 & 5.518 .226 & 28.452 & 28.980 & 29.753 & 18.710 \\
\hline $\begin{array}{l}\text { İşyeri Açma } \\
\text { İzni Harcı }\end{array}$ & 63.259 & 79.096 & 61.556 & 4.741 & 47.103 & 4.321 & 11.470 & 12.094 & 8.375 \\
\hline $\begin{array}{l}\text { Kaynak Suları } \\
\text { Harcı }\end{array}$ & 6.995 & 7.530 & 6.025 & 1 & 5.203 .013 & 0 & 0 & 0 & 0 \\
\hline $\begin{array}{l}\text { Ölçü ve Tartı } \\
\text { Aletleri } \\
\text { Muayene Harcı }\end{array}$ & 1.000 & 1.092 & 867 & 230 & 119.473 & 173 & 94 & 161 & 89 \\
\hline $\begin{array}{l}\text { Tatil Günle- } \\
\text { rinde Çalışma } \\
\text { Ruhsatı Harcı }\end{array}$ & 3.830 & 4.670 & 3.632 & 257 & 148.637 & 392 & 246 & 195 & 450 \\
\hline Tellallık Harcı & 85.644 & 107.834 & 59.528 & 9.860 & 339.695 & 7.493 & 15.072 & 17.763 & 11.190 \\
\hline $\begin{array}{l}\text { Yapı Kullanma } \\
\text { İzni Harcı }\end{array}$ & 238.502 & 192.088 & 150.831 & 19.402 & 457 & 11.882 & 3.322 & 1.808 & 1.344 \\
\hline TOPLAM & 3.758 .030 & 4.215 .560 & 3.239 .664 & 378.072 & 13.266 .852 & 349.720 & 509.771 & 509.494 & 364.044 \\
\hline
\end{tabular}

Kaynak: Muhasebat Genel Müdürlüğü’nün mahalli idareler bütçe istatistiklerinden yararlanılarak yazar tarafından düzenlenmiştir. https://muhasebat.hmb.gov.tr/mahalli-idareler-butce-istatistikleri, (17.03.2021).

$\left({ }^{*}\right)$ Emlak vergisi dahil edilmemiştir.

Yukarıdaki Tablo 2'de görüldügü üzere, 2020 yılında Türkiye'de belediye türleri itibarıyla Belediye Gelirleri Kanunu kapsamındaki yerel yönetim vergi ve harç gelirlerinin toplam tutarı içinde ilçe ve belde belediyeleri payı \%81,88, büyükşehir dışı il belediyeleri payı $\% 8,83$ ve büyükşehir belediyeleri payının ise $\% 9,20$ şeklinde gerçekleşmiştir. Dolayısı ile 2020 yılında Türkiye'de belediye türleri itibarıyla Belediye Gelirleri Kanunu kapsamındaki yerel yönetim vergi ve harç gelirlerinden en yüksek payı ilçe ve belde belediyeleri alırken, en düşük payı ise büyükşehir dışı il belediyeleri almıştır. 
Ayrıca Tablo 1'deki 2018-2020 yılları arasındaki üç yıllık dönemde Türkiye'de belediye türleri itibarıyla Belediye Gelirleri Kanunu kapsamındaki yerel yönetim vergi ve harç gelirlerinin 2018 yılına göre 2019 yılında artış göstermesine karşın, 2019 yılına göre 2020 yılında tüm gelir kalemlerinin toplam tutarında büyük tutarlarda gelir kaybının gerçekleştiği ve söz konusu gelir kaybı nedeninin Covid 19 pandemi salgınından kaynaklandığı değerlendirilebilir.

\section{Yerel Yönetim Gelirlerine İlişkin Öneriler}

Belediye gelirleri kanunu çerçevesindeki yerel yönetim vergileri, harçları, ücret ve katılım paylarından alınacak olan verimi artırıcı yöndeki uygulama ve düzenleme önerilerine aşağıda yer verilmiştir.

- Belediye Gelirleri Kanununun 14'üncü maddesinde yer alan ilan ve reklam vergisine ilişkin muafiyet ve istisna maddesi yeniden düzenlenerek; Türk Radyo ve Televizyon Kurumu tarafından yayınlanan ve yapılan ilan ve reklamlar istisna düzenlemesinden çıkartılmalıdır. Türk Radyo ve Televizyon Kurumu dışındaki özel radyo ve televizyon kurumları yayınlamış oldukları ilan ve reklamlar nedeni ile ilan ve reklam vergisi mükellefidirler. Yayınlanan ilan ve reklamlar nedeni ile yalnızca Türk Radyo ve Televizyon Kurumu'na istisna tanınmış olması, gerek rekabet hukuku açısından gerekse belediye gelirleri açısından olumsuzluklara neden olmaktadır.

Belediye Gelirleri Kanununun 14'üncü maddesinde yer alan ilan ve reklam vergisine ilişkin muafiyet ve istisna maddesinde çerçevesinde her türlü gazete, dergi ve kitaplarda yapılan ilan ve reklamlar istisna kapsamında yer almaktadır. Kültürel açıdan son derece olumlu olan söz konusu düzenleme, internet üzerinden yapılan yayınları da (e-gazete, e-dergi ve e-kitaplar) kapsayıcı yönde genişletilmelidir.

- Belediye Gelirleri Kanunu kapsamında verilen yerel yönetimler beyanname ve bildirimleri elektronik ortamda verilmelidir. (yerel beyanname -ye-beyanname-, yerel bildirim -ye-bildirim-) Belediye Gelirleri Kanunu kapsamında verilen yerel yönetimler beyanname ve bildirimlerinin elektronik ortamda verilmesi, gerek süre gerekse denetim açılarından büyük yarar sağlayacaktır.

- Belediye Gelirleri Kanunu kapsamında yerel yönetimler tarafından yapılan yoklama, haciz ve tebligat işlemleri elektronik ortamda yapılmalıdır. (ye-yoklama, yehaciz, ye-tebligat) Belediye Gelirleri Kanunu kapsamında yerel yönetimler tarafından yapılan yoklama, haciz ve tebligat işlemlerinin elektronik ortamda yapılması, takip ve denetim açılarından olumlu sonuçlar verecektir.

- Belediye Gelirleri Kanunu kapsamında verilen yerel yönetimler beyanname ve bildirimlerinin belirli süreler içinde, Hazine ve Maliye Bakanlığı Vergi Denetim Kurulu Vergi Müfettişleri tarafından incelenmesi sağlanmalıdır. 
- Yerel yönetimlerin mali yapılarını güçlendirmek amacıyla öz gelirleri artırılmalı ve Belediye Gelirleri Kanunu yeniden düzenlenmelidir (T.C Cumhurbaşkanlığı Strateji ve Bütçe Başkanlığı, 2019: 47).

- Öz gelirleri artıracak önemli bir kaynak ise yerel vergilerdir. Yerel yönetimler bu konuda (vergilendirme ve kaynak yaratma) daha geniş yetkilerle donatılmalı ve bu yetkilerin yaşama geçirilmesini sağlayacak kurumsal düzenlemeler yapılmalıdır (Tavşancı, vd., 2009: 250).

Kurumsal düzenlemeler çerçevesinde Türkiye'deki tüm yerel yönetimleri kapsayacak şekilde "Yerel Yönetimler Bakanlığı" kurularak, il, ilçe ve büyükşehir belediyelerinin tüm iş ve işlemleri söz konusu bakanlık aracılığı ile gerçekleştirilerek, tüm belediyeler kurumsal olarak güçlendirilmelidir.

- 2005 yılı başında 2464 sayılı Kanunda yapılan güncelleme dışındaki yerel vergilerin, enflasyon karşısında gelir yaratma kapasitelerindeki düşüş ve yönetim maliyetindeki artış şeklindeki olumsuzlukların giderilmesi için gerekli düzenlemelerin yapılması gerekmektedir (Armağan, vd., 2009: 246).

- 7221 Sayılı Coğrafi Bilgi Sistemleri ile Bazı Kanunlarda Değişiklik Yapılması Hakkında Kanun'un 12'nci maddesi ile 3194 sayılı İmar Kanununa ek 8'inci madde eklenerek, bir tür "İmar Rantı Vergisi" niteliğinde olan "Değer Artış Payı" 19.02.2020 tarihinden itibaren uygulanmaya başlanmıştır. Yapılan düzenlemeye göre; taşınmaz maliklerinin tamamının talebi üzerine ada bazında yapılacak imar planı değişikliği sonucunda değerinde artış olan arsanın artan değerinin tamamı değer artış payı olarak alınmaktadır.

Taşınmazların malikleri tarafından, değer artış payı tutarları Çevre ve Şehircilik Bakanlığı muhasebe birimi hesabına yatırılmakta ve yatırılan tutarların;

i. Büyükşehir belediyesinin olduğu illerde; \% 25’i büyükşehir belediyesinin ilgili hesabına, \% 25'i ilgili ilçe belediyesinin ilgili hesabına, \% 25’i Bakanlığın Dönüşüm Projeleri Özel Hesabına,

ii. Büyükşehir belediyesi olmayan illerde ise; \% 40’ı imar planı değişikliğini onaylayan idarede açılacak ilgili hesaba, \% 30'u Bakanlığın Dönüşüm Projeleri Özel Hesabına,

iii. Bakanlıkça onaylanan imar planı değişikliğinden kaynaklanan değer artışının \% 75'i Bakanlığın Dönüşüm Projeleri Özel Hesabına, kalan değer artış payının; büyükşehir belediyesinin olduğu illerde \% 15'i büyükşehir belediyesinin ilgili hesabına, \% 10'u ilgili ilçe belediyesinin ilgili hesabına; büyükşehir belediyesi olmayan yerlerde ise Bakanlık payının dışındaki kalan değer artış payının tamamı plan değişikliğinin yapıldığı yerdeki ilgili idarenin açılacak ilgili hesabına, beş iş günü içerisinde aktarılmaktadır.

Yukarıda yer alan ve bir tür "İmar Rantı Vergisi" niteliğinde olan "Değer Artış Payı", bütünüyle taşınmazın bulunduğu yerel yönetimler ile ilgili olmasına ve söz 
konusu payın tamamının ilgili belediye kaynağı olması gerekirken, ancak belirli bir yüzdesi yerel yönetimlere kaynak teşkil etmektedir.

Düzenleme mevzuat olarak aynı şekilde uygulanmalı, ancak değer artış payının tamamının ilgili yerel yönetimlere aktarılmasının sağlanması gerekir.

- Büyükşehirlerde ilan ve reklam vergisini toplamaya genel yetkili belediye ilçe belediyesidir. Büyükşehir belediyeleri ise sadece kanunda sayılan belirli yerlerde bu vergiyi tahsil edebilir. Fakat bu durum pratikte büyükşehir belediyesi ile ilçe belediyesi arasındaki sorunlara yol açmaktadır. Gerek bu sorunları ortadan kaldırmak gerekse verginin tahsilini daha verimli kılmak adına, büyükşehirlerde ilan ve reklam vergisi toplama yetkisi ilçe belediyelerine bırakılmalıdır (Duru, 2020: 842).

\section{Sonuç}

Ülkemizde Emlak Vergisi Kanunu ve Belediye Gelirleri Kanununda yer alan yerel yönetimlere ilişkin vergi, harç, ücret ve katılım payları, yerel yönetimlerin en önemli gelir kaynaklarını oluşturmaktadır. Belirtilen yerel yönetim gelirlerinin toplanması ilgili belediyeler tarafından yerine getirilirken, söz konusu gelirlere ilişkin mevzuat düzenlemesi ve mevzuata ilişkin yön vermek işlemi, Çevre ve Şehircilik Bakanlığı Yerel Yönetimler Genel Müdürlüğü aracılığı ile Hazine ve Maliye Bakanlığı Gelir İdaresi Başkanlığı tarafından yerine getirilmektedir. Yerel yönetimlerin vergi, harç, ücret ve katılım paylarına ilişkin mevzuat ile ilgili olarak çeşitli tarihlerde çeşitli değişiklik ve güncellemelerin yapılmış olmasına karşın, söz konusu mevzuatın temel yapısının kırk yıllık süreçte değişime uğramamış olması uygulamada sorunların ortaya çıkmasına neden olmaktadır. Bu çerçevede Belediye Gelirleri Kanununa ilişkin olarak hazırlanmış, ancak 27.05.2008 tarihinde Türkiye Büyük Millet Meclisi'nden geri çekilmiş olan 25.09.2006 tarihli İ Özel İdaresi ve Belediye Gelirleri Kanunu Tasarısının güncellenerek tekrar kamuoyunda tartışılarak dikkate alınması ve böylece Belediye Gelirleri Kanunun güncel sürece uygun bir şekilde yenilenmesi yerel yönetimlere ivme kazandıracaktır. Ayrıca, Merkezi Yönetim Bütçesi dışında kendilerine ait yerel yönetim bütçesine sahip olan yerel yönetimlerin "Yerel Yönetimler Bakanlığı" adı altında tek bir bakanlık yapısı içinde teşkilatlanmalarının sağlanması, belediye hizmetlerinin etkin kullanımının yanı sıra belediye gelirlerinin tahsil ve takibinde yerel yönetimlerin güçlenmesine katkı yapacaktır. Yerel yönetim gelirlerine ilişkin mevzuat düzenlemelerinde ve kurumsal yapı çerçevesinde yapılacak olan söz konusu değişimler yerel yönetim uygulamalarına erişim, yerel yönetimlerin denetim ve hizmet sunumlarında etkinliğin artmasına neden olacaktır. 


\section{Kaynakça}

Arıkboğa, Ü. (2015). "Türkiye'de Yerel Vergi Yönetimi”, Maliye Dergisi, 168, 1-19.

Arıkboğa, Ü. (2016). "Türkiye'de Belediyelerin Gelir Yapısı: Sorunlar ve Çözüm Önerileri", Mustafa Kemal Üniversitesi Sosyal Bilimler Enstitüsü Dergisi, 33, 276297.

Armağan, R. \& Şataf, C. (2009). "Belediyelerin Mali Kaynaklarını Geliştirme Açısından Yerel Vergiler Ve Etkinliği Üzerine Bir Değerlendirme”, Vergi Sorunları Dergisi, 246, 193-220.

Aslan, M. (2014). "Kentsel Rantların Vergilendirilmesi", Ankara Barosu Dergisi, 3, 116134.

Bülbül, D. (2013). "Yerel Yönetimlerde Yeni Bir Finansman Yöntemi: Günah Vergileri", Vergi Sorunları Dergisi, 294, 167, 166-170.

Duru, A., A. (2020). "Belediyelerin İlan ve Reklam Vergisi Uygulamaları Üzerine Bir Değerlendirme", Anemon Muş Alparslan Üniversitesi Sosyal Bilimler Dergisi, 8(3), 831-843.

Hacıköylü, C. (2016). "Taşınmazların Elden Çıkarılmasında Elde Edilen Kazançların Vergilendirilmesi: Yeni Gelir Vergisi Kanun Tasarısının Getirdikleri”, International Journal of Public Finance, 1-2, 194-219.

Önder, A. Özkök Çubukçu, D. (2017). “Beyoğlu Belediyesi Örneğinde Yerel Kamu Hizmetlerinin Taşınmaz Vergi Değerlerine Etkisi-l”, Vergi Sorunları Dergisi, 349, 108-122.

Önder, A. Özkök Çubukçu, D. (2017). “Beyoğlu Belediyesi Örneğinde Yerel Kamu Hizmetlerinin Taşınmaz Vergi Değerlerine Etkisi-II", Vergi Sorunları Dergisi, 350, 40-61.

Öz, N. S. (2012). “Anayasa Mahkemesinin Belediye Meclislerinin Vergilendirme Yetkisiyle İlgili Kararına İlişkin Bir Değerlendirme", Ankara Üniversitesi SBF Dergisi, 64, 63-88.

Şahin İpek, E, A. (2018). "Türkiye'de Belediye Gelirlerinin Değerlendirilmesi", Kocatepe Üniversitesi Iktisadi ve Idari Bilimler Fakültesi Dergisi, 20(2), 1-19.

Tavşancı, A. Keçeci, B. (2009). “Avrupa Birliği Sürecinde Yerel Yönetimlerin Vergilendirme Yetkisi ve Anayasal Çerçeve", Vergi Sorunları Dergisi, 250.

T.C. Cumhurbaşkanlığı Strateji ve Bütçe Başkanlığı. (2019). On Birinci Kalkınma Planı 2019-2023, Ankara.

T.C. Kalkınma Bakanlığı. (2014). Onuncu Kalkınma Planı 2014-2018 Vergi Özel ihtisas Komisyonu Raporu, Ankara.

T.C. Kalkınma Bakanlığı. (2018). On Birinci Kalkınma Planı (2019-2023) Yerel Yönetimler ve Hizmet Kalitesi Özel Ihtisas Komisyonu Raporu, Ankara. 
Ulusoy, A. (2000). "Yerel Yönetimler ve Vergilendirme Yetkisi", Vergi Sorunları Dergisi, $145,130-143$.

Ulusoy, A. \& Tekdere, M. (2019). “Türkiye'deki Belediyelerin Mali Sorunları ve Muhtemel Etkiler", Türkiye Bilimsel Araştırmalar Dergisi (IBAD), 2, 167-182.

Yerel Yönetimler Genel Müdürlüğü. (2019). 2018 Yılı Mahalli Idareler Genel Faaliyet Raporu, Ankara.

Yılmaz, N. (2008). "Bir Otokontrol Sistemi Olarak Belediyelerde Harcamalara Katılma Payı", Sayıştay Dergisi, 71, 75-90.

Yiğit, U. \& Öztürk, ì. (2017). "Vergi Benzeri Mali Yüküm Niteliğindeki Belediye Gelirlerinin Haczedilebilirliği", Vergi Sorunları Dergisi, 350, 62-84.

Yüksel, F. (2003). "Belediye Gelirlerinde Yetersizlikler ve Alternatif Çözüm Önerileri", Selçuk Üniversitesi iktisadi ve Idari Bilimleri Fakültesi Sosyal Ekonomik Araştırmalar Dergisi, 6, 49-60. 